\title{
Towards a Model of Olympic Social Capital: Theory and Early Evidence
}

\author{
Nathalie Prüschenk ${ }^{1, *} \&$ Markus Kurscheidt ${ }^{1}$ \\ 1 Institute of Sport Science, Department of Sport Governance and Event Management, University of Bayreuth, Bayreuth, Germany \\ * Corresponding author: Institute of Sport Science, University of Bayreuth, Universitätsstr. 30, D-95448 Bayreuth, Germany \\ Tel: +49 (0) 921-553481, Fax: +49 (0) 921-553468 \\ E-Mail: nathalie.prueschenk@uni-bayreuth.de
}

\section{ORIGINAL ARTICLE}

\section{Article History:}

Submitted $10^{\text {th }}$ May 2019

Accepted $12^{\text {th }}$ December 2019

Published $13^{\text {th }}$ February 2020

Handling Editor:

Martin Kopp

University of Innsbruck, Austria

Editor-in-Chief:

Martin Kopp

University of Innsbruck, Austria

Reviewers:

Reviewer 1: Anonymous

Reviewer 2: Anonymous

\section{ABSTRACT}

Regarding sports, it has been argued that social capital is created by value-based cultural practices and social exchanges. However, empirical evidence is scarce and does not capture causal relationships. Therefore, the purpose of this article is to develop a causal model of social capital formation within the Olympic movement as an exemplary case of value-based cultural practices in sports. The model focuses on the bridging capital accumulated by Olympic spectators. The main theoretical insight is that the interrelationship among the three Olympic key values of respect, friendship and excellence is perceived and adopted by live spectators via a cyclic process of simultaneous experience resulting in a sustainable episodic memory. In contrast, broadcast spectators develop a dichotomous semantic memory that is negatively influenced by tensions in the socioeconomic environment. The plausibility of the model's propositions is illustrated by data from a cluster sample $(\mathrm{N}=1,703)$ of German broadcast spectators of and visitors to the 2016 Summer Olympics and 2016 Winter Youth Olympic Games. Notably, the Olympic social capital among the live attendees is found to be significantly larger than that among the broadcast spectators, while the evidence concerning the emotional exposure of the live visitors is mixed and warrants further research.

Keywords:

social capital - social exchange theory - Olympic Games - Olympic values - Olympism - International Olympic Committee - sport spectators - sport broadcast

Citation:

Prüschenk, N. \& Kurscheidt, M. (2020). Towards a Model of Olympic Social Capital: Theory and Early Evidence. Current Issues in Sport Science, 5:001. doi: 10.15203/CISS_2020.001.

\section{Introduction}

Olympic values form the core of the Olympic Games and are considered a unique selling proposition of the Olympic movement (International Olympic Committee [IOC], 2015). The Olympics are supposed to propagate a life model that consists of the interplay of work ethic, moral performance, social responsibility, respect for global ethical principles and learning through exchange and education (Coubertin, 2000). The use and transfer of these Olympic values create social capital within society. The complex levels of the underlying social interactions must be thoroughly examined to derive effective governance of such a common good (Berkes, 2008). In addition to the targeted activities of key influencers, the IOC and Organising Committee for the Olympic Games (OCOG), this requires the integration of all stakeholders in the Olympic movement (Davis, 2012) based on a large-scale perception and adoption of Olympic values.

However, the societal desire to create positive reinforcement can provoke the opposite, a negative reinforcement entailing the erosion of values (Skinner, 1948). One example of this phenomenon is the Olympic Games' profound turn to commercialisation (Dauvergne \& Lister, 2012; Seguin, Richelieu, \& O'Reilly, 2008). This may generate negative perceptions by the directly 
and most affected stakeholders, in particular, athletes and residents of Olympic host cities. Increasingly, spectators also hold a critical stance depending on the level of their awareness and information behaviour. The more they have a sense of social responsibility, the more they may develop a negative image of the Games or even refuse them (Andorfer, 2013; Barnett, Cloke, Clarke, \& Malpass, 2005). The result of these tensions could indeed be an erosion of the social capital created by Olympic values. Therefore, communication campaigns, when bidding for and staging Olympic Games, have to be credible and verifiable (Kurscheidt \& Prüschenk, 2020). However, this is largely a question of given socioeconomic constellations that have to be further empirically investigated (Prüschenk \& Kurscheidt, 2017; Schnitzer, Walde, Scheiber, Nagiller, \& Tappeiner, 2018).

In general, there is a substantial need for empirical studies on social capital related to a variety of social phenomena (Schuller \& Field, 1998). However, Mouw (2006) notably criticised social capital theory for its lack of foundations of causal relationships, which represents a significant restriction on precise measurement. For instance, regression analyses test causal empirical models and may therefore not be applicable to studies on social capital, although they are best suited to identify hidden relationships in complex social environments. Prüschenk and Kurscheidt (2017) were the first to show the explanatory power of such an empirical approach to social capital in the Olympic context. They found that the Youth Olympic Games (YOG) may be an effective instrument to shift perceptions of Olympic values (see also Schnitzer et al., 2018). These insights could be derived from the causal relationships only in multiple regressions. Therefore, the aim of this article is to develop a causal model of the social capital created by Olympic values with a focus on the largest stakeholder group of spectators. The theoretical reasoning and modelling of causalities could enhance the understanding of the process by which social capital is created in different contexts of Olympic Games and the moderating variables that could prevent spectators from contributing to social capital creation. Since the model is restricted to the particular characteristics of the context of the Olympic movement and the Olympic Games, this specific construct will be called 'Olympic capital'. Regarding the focus on the perception of spectators, live spectators must be distinguished from broadcast spectators. While the former are a smaller group than the latter, they are much more exposed to the experience of the Olympic values. Social capital creation among spectators will be argued following Bourdieu's $(1984,1986)$ and Putnam's $(2000)$ theories of social capital and social exchange theory (Emerson, 1976). Finally, the plausibility of the key propositions of the model is illustrated by data from cluster surveys $(N=1,703)$ of live spectators at the 2016 Summer Olympics and 2016 Winter YOG compared to German broadcast spectators of the 2016 Rio de Janeiro Games.

In the following section, the model is reasoned in two major steps. First, the creation of social capital by Olympic values is argued. Second, the social exchange of Olympic messages and symbolism experienced by live spectators compared to broad- cast spectators is modelled. The third section introduces the methods and data, while the fourth section presents early evidence for the model's propositions. The final section concludes with first insights and an outlook on follow-up research needed to advance the model and empirical findings on Olympic capital.

\section{Modelling Olympic Capital Creation}

\section{Olympic Values, Social Capital and Spectator Perception}

The guiding principle of Olympism is summarised into three core values: respect, friendship and excellence (IOC, 2015). These are understood worldwide and apply to humanity in general, not just to athletes and spectators at the Olympics. Initially, Olympic values affect the athletes who actively shape the Games and represent the heart of the Olympic movement (IOC, 2014). The construct of Olympism may be split into three components as a function of the social context (Bourdieu, 1984): Olympism through (1) active sports, (2) local live consumption and (3) (global) broadcast consumption.

By its nature, active sports embody the central values of Olympism. Thus, athletes can actively experience Olympic values at the Olympic Games. They are supposed to show respect towards the achievements of other athletes, which is reinforced when respect is returned in a social exchange within the contest environment. The friendship based on such mutual regard, trust and tolerance forms the centre point of Olympism (Putnam, 2000; Schulenkorf, 2010, 2012). It aims for an exchange among all parties involved and is associated with further values such as dialogue, diversity and solidarity. Excellence requires giving the best of oneself in every context of life (IOC, 2013). These values build a social context and become relational qualifications through social interaction (Coleman, 1990; Esser, 1999). Social capital is notably created when the values are simultaneously experienced (Bourdieu, 1986). The IOC uses the Olympic values originating from active sports, generalises them and purposefully places them into the wider social context of spectators.

Various studies have shown how active sport contributes to conveying and strengthening values by social exchange (Coalter, 2008; Downward, Pawlowski, \& Rasciute, 2014; Nicholson \& Hoye, 2008; Skinner, Zakus, \& Cowell, 2008). Hence, social capital is substantially created in mass amateur sports, since it is consistent with sport's primary function of joint physical activity and fostered by socialisation in sport clubs (Lindström, Hanson, \& Östergren, 2001; Nicholson \& Hoye, 2008). In the context of professional sports, social capital has been used as a general theoretical explanation for socioeconomic outcomes of major sport events. They are argued to generate social capital that may be leveraged to improve economic transactions and impacts (Groeneveld, Houlihan, \& Ohl, 2011; Misener \& Mason, 2006; Spaaij \& Westerbeek, 2010). Other articles consider social capital an outcome that is typically limited to the period of the Olympic Games unless social strategies are intentionally 
incorporated into the hosting strategy, such as the 2000 Sydney Olympic Games strategy of inclusion of Australian aborigines (Koenigstorfer et al., 2019). Therefore, the Olympic Games have the potential to induce changes in the beliefs of residents and spectators when targeted in the hosting policy (Prüschenk \& Kurscheidt, 2017; Schnitzer et al., 2018). In particular, Olympic experiences may inspire both residents and spectators by the Olympic idea. As a result, they tend to be less critical about the size and costs of the Olympics (Kurscheidt \& Prüschenk, 2020) and to support future bids for the Games (Schnitzer, Walde, Scheiber, Nagiller, \& Tappeiner, 2019). However, changes in beliefs do not necessarily cause changes in habits (Preuss, 2019). Moreover, the mechanisms of the transmission and adoption of Olympic values as a function of the given socioeconomic environment is not sufficiently addressed in this literature. Thus, this article attempts to theoretically model these mechanisms while focusing on spectators of Olympic Games.

The consumption of sport spectators is characterised by heterogeneity, complex behaviours and attitudes influenced by the social context (Bouchet, Bodet, Bernache-Assollant, \& Kada, 2011; Van Leeuwen, Quick, \& Daniel, 2002). In addition, following the theory of two-sided markets, the broadcast demand for a sporting event depends on the general interest for the event as documented by the live attendance. However, increasing commodification and commercialisation may generate mistrust from the public and harm the attachment of sport fans (Block \& Polanyi, 2003; Giulianotti, 2005). In such a social environment dominated by business and political interests, the principles of Olympism are likely to be undermined and become ineffective. Silk, Andrews, and Cole (2005), for instance, conclude that the key product of the Olympic Games is no longer international understanding, as embodied in the Olympic values, but instead global capitalism and consumption.

Thus, Olympism has become a by-product of the Games, which currently are a unique global entertainment product serving diverse politico-economic interests. This has provoked substantial opposition worldwide against the Olympic Games and IOC over the past two decades (Shaw, 2008; Simons, 2015). Hence, the controversial social context of the Olympic Games has to be taken into account when modelling social capital among spectators created by Olympic values.

\section{Olympic Capital Created by Olympic Values}

The social capital generated by the Olympic movement should be examined on the basis of the following three fundamental forms of social capital (Prüschenk \& Kurscheidt, 2017) introduced by Woolcock (1998) and Putnam (2000): bonding, bridging and linking capital. Therefore, the basic model of Olympic capital depicted in Figure 1 is developed through a theoretical analysis of the three forms of social capital based on the Olympic values. This leads to the identification of components and mechanisms of social capital creation to be discussed in the following.

Bonding capital is typically found in communities that tend to be smaller, strongly interconnected and homogeneous. This is the case in active sports (Downward et al., 2014) and may also apply to athletes at Olympic Games (Schulenkorf, 2010). Both the concept of nation, linking the teams that compete at the Olympics, and the common ideals of sports, embracing all athletes, create strong connections among the participants. Moreover, they share the same experiences, have to meet the same requirements given by the regulations of the Olympic Games and pursue the same target of showing sporting performance.

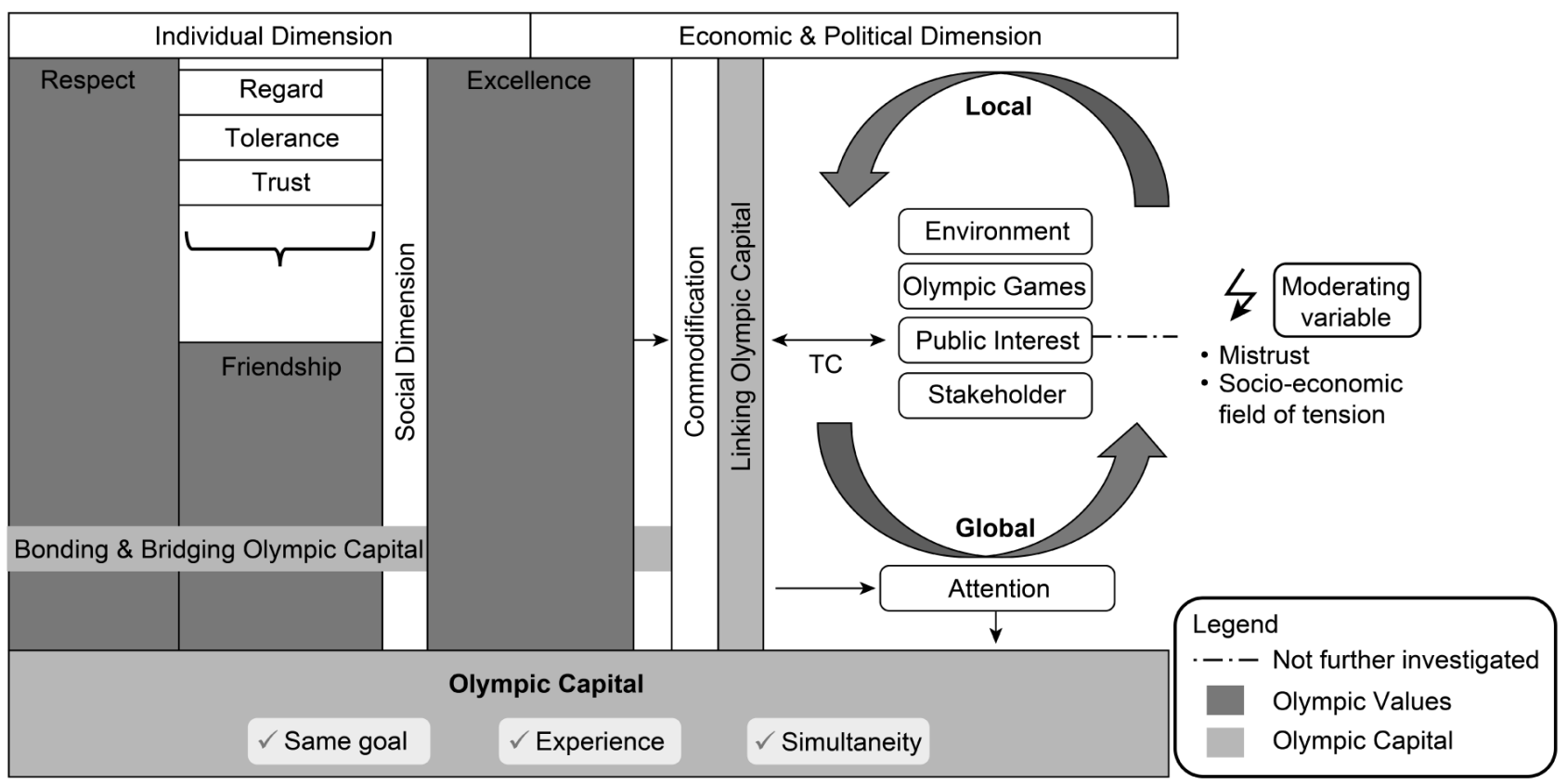

Figure 1. Olympic capital created by Olympic values. 
Hence, despite the competition among athletes, they build a community fulfilling three criteria of effective social capital formation: same goal, experience and simultaneity (Bourdieu, 1986).

Spectators, in contrast to the athletes, do not necessarily have common goals, though the social and economic needs and preferences that induce their sport consumption will be similar (Trail, Fink, \& Anderson, 2003). In addition, depending on the type of consumption (live vs. broadcast) and emotional exposure, spectators are interconnected by either a strong or weak social exchange (Granovetter, 1973; Koo \& Hardin, 2008). Certainly, however, their social ties as a large group of live attendees and worldwide TV viewers are not as close as those of athletes at the Games. Thus, their interrelations rather constitute bridging capital as opposed to the stronger bonding capital in the case of athletes (Prüschenk \& Kurscheidt, 2017). However, both forms of Olympic capital are to be found on the horizontal level in the model of Figure 1 because both arise from a decentralised mutual exchange of the involved communities and stakeholders. The IOC and the OCOG cannot directly control this process or intervene effectively (Christesen, 2015), but they may provide structures and platforms related to the Games that facilitate social capital formation among the involved groups (Misener \& Mason, 2006) by benefitting from processes of value co-creation (Horbel, Popp, Woratschek, \& Wilson, 2016; Woratschek, Horbel, \& Popp, 2014).

In contrast, linking capital is directly influenced, i.e., on the vertical level in Figure 1, by the IOC, business representatives and sponsors (Christesen, 2015; Preuss, 2007b; Walker, Heere, Parent, \& Drane, 2010; Xing et al., 2008). It emerges from institutionalised interrelations of stakeholders in the economic and political dimension of the Olympic movement and builds upon the bonding and bridging capital created in the social dimension. At the intersection of these dimensions, the commodification of the Olympic Games represents a major leverage for Olympic capital. The exciting and outstanding sporting performance, following the Olympic value of excellence, determines the entertainment product that generates global awareness, which, in turn, drives the advertising product of the Olympics. As a result, the overall Olympic capital is multiplied by the forces of the market mechanism.

However, this sphere of the model in Figure 1 is fraught with tensions caused by the diverging logics of social and professional interactions. Therefore, the Olympic value of excellence has become ambivalent in relation to social capital creation. For instance, the criticism has been presented that the athletes are transformed from social actors into producers striving for economic optimisation (Digel, 2008). At the same time, governmental and sport officials contend that elite sport encourages participation in sports and social communities (Grix \& Carmichael, 2012). Hardly any nation has not utilised sport and the Olympics as a strategic instrument for pursuing politico-economic interests (Houlihan \& Green, 2008). However, while the tensions have been extensively discussed in the international literature (Grix \& Houlihan, 2014; Houlihan, 2012; Houlihan
\& Zheng, 2013; Minnaert, 2012; Preuss, 2004; Preuss, 2007a, 2019), the virtues of commodification and professionalisation have been largely overlooked.

Christiansen (2010) found, for example, that elite athletes perceive themselves rather as professionals and appreciate the global visibility of elite sports and the Olympics. As argued above and in the model, Olympic capital creation starts with the individual dimension of the athletes who experience and practise Olympic values. Apparently, they manage to unite the mentioned competing logics in their self-concept. Actually, this is in line with early writings on social exchange theory. Blau (1964) argued social exchange as being linked to economic organisation since it provides the incentive framework for social interaction. Moreover, basic values are not lost with economic development (Inglehart \& Baker, 2000). The resulting bonding and bridging capital is rather supplemented by the linking capital of commodification, which is also value based in the Olympic context concerning the value of excellence. Thus, it is rather a question of effective governance how this commodification impacts Olympic capital creation. Efficient institutions may reduce transaction costs (Coase, 1998) and, thereby, enable a smoother and quicker dissemination of Olympic capital. An important outcome is notably the unprecedented global media coverage of the Olympic Games (Black, 2007; Payne, 2006). This guarantees the tremendous worldwide awareness that generates the 'feel-good factor' as evidenced in major sport events (Kavetsos \& Szymanski, 2010), which may also be attributed to the appreciation of Olympic values.

Hence, the mechanism of Olympic capital creation begins with the athletes practising respect (e.g., fairness in sport contests) and friendship (e.g., team spirit), but, at the same time, showcasing excellence (in particular, outstanding sporting performance). The commodification and mediatisation of Olympic excellence then turn the origin of Olympic capital from the micro-level of the individual dimension into a collective phenomenon on the macro-level of social dimension. Thus, the theoretical analysis confirms that Olympic values indeed provide a potentially powerful platform for the Olympic Games to build bridging and linking capital also collectively among the worldwide spectatorship. This insight can be particularly derived from the perspective of social exchange theory on the link between the individual and collective formation of social capital (see also Brandes, Dharwadkar, \& Wheatley, 2004; Burt, 1997; First, 2017). However, communication channels play an important role in facilitating the social interaction between individual bridging groups and linking institutions (Mohr \& Sohi, 1996). These issues of spectator perception of Olympic values will be argued in the following and modelled by Figure 2.

\section{Transfer of Olympic Capital to Spectators by Social Exchange}

The global attention of the Olympic Games must be leveraged to convey Olympic values to the spectatorship. Generally, social capital is increasingly perceived, the more attention the good (i.e., the Olympic Games) and its attributes (i.e., Olympic values) 


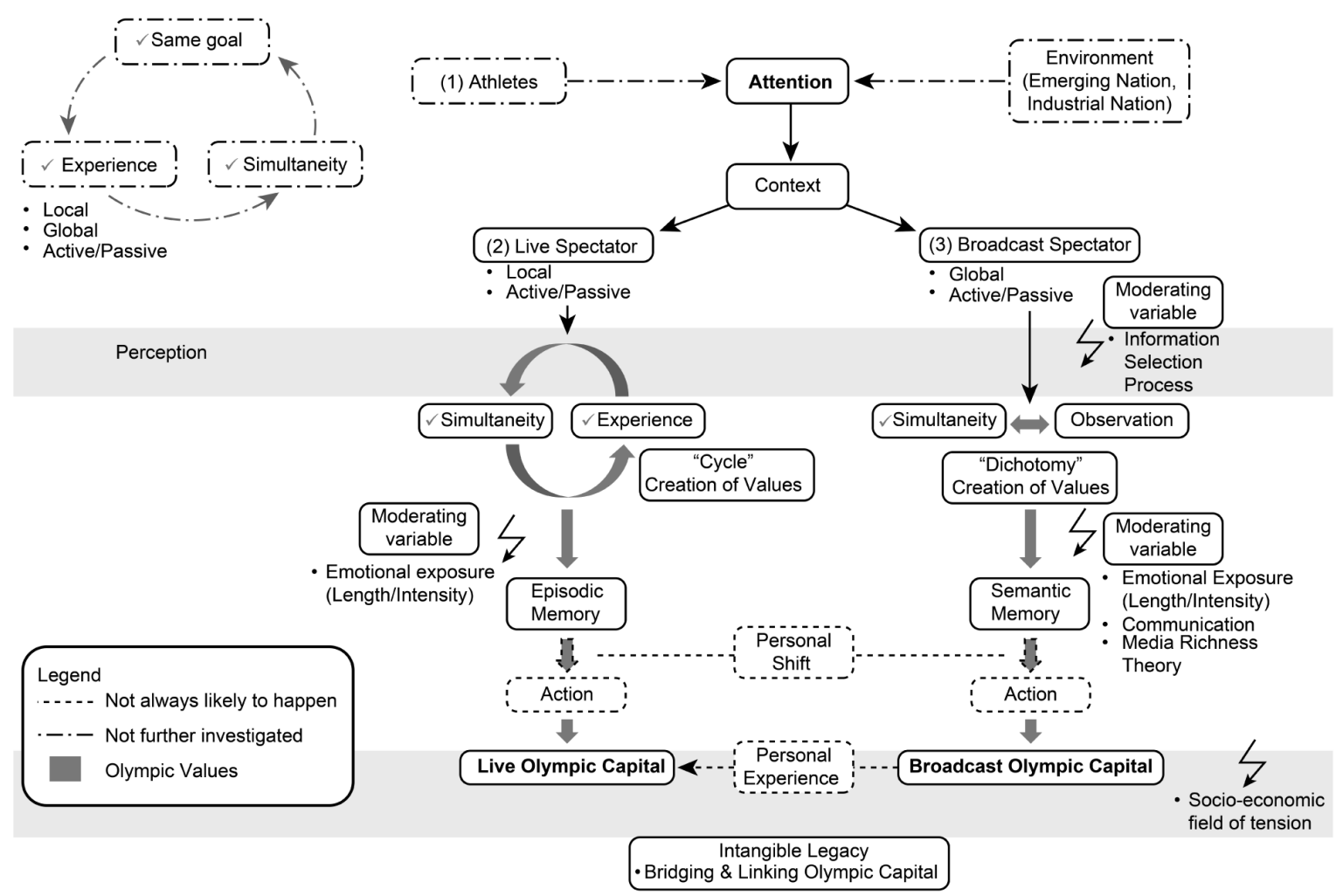

Figure 2. Olympic capital creation among spectators by social exchange.

receive (Ferrand \& Pages, 1999; Mackenzie, 1986). In addition, the higher is the individual engagement with the object of social capital creation and the greater is the personal exposure, the larger the social capital generated (Misener \& Mason, 2006; Olney, Holbrook, \& Batra, 1991; Schulenkorf, 2009). However, the groups of spectators may not only differ in exposure to the Olympic Games but also perceive Olympic messages in varying contexts (Vargo \& Lusch, 2016). Therefore, spectators from diverse national and cultural backgrounds may have different access to Olympic capital. In addition, the level of involvement has an impact on the perception of Olympic issues (Kurscheidt \& Prüschenk, 2020; Schnitzer et al., 2018), such as future support of Olympic bids (Schnitzer et al., 2019). Moreover, viewers who collectively follow the Olympics (e.g., in a sports bar) are expected to have a different perception from those watching individually at home (Woratschek, Durchholz, Maier, \& Ströbel, 2017). While such differentiations could be subject to further research, the following model in Figure 2 focusses on live spectators compared to broadcast spectators (Morley \& Robins, 2002).

Live spectators. Individuals attending the Olympic Games may share similar consumption motives and have comparable experiences. Their perception is influenced by the following two major determinants of Olympic capital creation: simultaneity and experience. Simultaneous experiences may notably occur with regard to the atmosphere, entertainment, sporting competitions and cultural exchange (Chalip, 2006). Therefore, live spectators are not merely recipients but also actively shape the event through their social interactions (Horbel et al., 2016; Woratschek et al., 2014). Thus, such a social exchange should be understood as a cycle rather than a dichotomy (Crawford, 2004; Mehus, 2005). It is based on information and values that depend on the individual's experience (Cook \& Rice, 2003; Emerson, 1976; Homans, 1961; Leik, 1992; Skinner, 1953). The personal exchange produces individual and social stimuli that create an atmosphere of learning (Atkinson \& Wickens, 1971; Broadbent, 1963; Simon \& Newell, 1964; Thorndike, 1931).

In contrast to residents, whose quality of life is sometimes impaired by the hosting of the Olympic Games (e.g., by congestions, noise and crime; Schulenkorf \&Edwards, 2012), spectators are only temporarily affected in a comfortable leisure context. The more they are involved and the more intense are their interactions with a large group of other spectators, the larger is the value created for all attendees (Horbel et al., 2016; Vargo, Maglio, \& Akaka, 2008; Woratschek et al., 2014). In addition, common values may be mutually confirmed (Hofer, Reinders, \& Fries, 2010). While attendees encounter each other and engage in intercultural contacts, they however maintain their national and social identities but share the special moments and may communicate intensely. The greater the personal input as well as the length and intensity of the emotional exposure (moderating variable), the more likely the experience is to remain in the spectators' memories (Thorson, Chi, \& Leavitt, 1992). This form of recalling emotional experiences is called episodic memory and is characterised by the fact that it is lived. Therefore, it can be saved as a long-term memory whose importance 
is memorised proportionally to the duration of the experience (Conway, 1997). It moreover stimulates interaction with the environment (Glenberg, 1997) and further commitment (e.g., volunteering activity; Green \& Chalip, 2004).

Irrespective of the tensions discussed above, live spectators enjoy a positive personal experience. However, this individual and emotional experience cannot be transferred to other locations (e.g., fan meetings such as public viewings; Uhrich \& Benkenstein, 2010; Woratschek et al., 2017). This kind of social capital is inaccessible to other spectator groups because it has to be personally experienced. Observers may notice only the local atmosphere, which might stimulate their interest in attending. In the model, this special form of an intense bridging capital shall be called live Olympic capital. This can make attendees of Olympic Games into ambassadors of Olympic values recommending the live experience to others. In contrast, low involvement of live spectators can result in low emotional attention. This leads to inattentional blindness (Mack \& Rock, 1998; Simons, 2000) and causes the Olympic capital to not be perceived (Rensink, O'Regan, \& Clark, 1997).

Broadcast spectators. The strong personal experience of live spectators is not accessible to TV viewers. Their perception of the broadcast is embedded in everyday life and is part of an information selection (Fisher \& Naumer, 2006). It is not as conscious a decision as taking vacation, travelling to the Olympic Games and attending live. In the model, the information selection is therefore understood as a moderating variable in a continuous process of attention and perception of the daily routine. It also depends on the schedules of the coverage of the Olympic Games in various communication channels, such as television, the Internet, social media and newspapers (Thompson, 1995). However, media consumers do have a pronounced interest in the Olympic Games since it is easy for them to switch off or turn away to another activity. Therefore, the simultaneity is given when they watch live broadcasts. However, there is no active social exchange or involvement of personal resources. Thus, their isolated viewing constitutes a dichotomy of value creation which is not based on an emotional exposure.

Depending on the length and intensity of the exposure, the broadcast spectator will keep the viewed content in mind. This is called semantic memory and is characterised by a conceptual knowledge obtained by observation (Conway, 1997). Consequently, broadcast spectators acquire a substantially weaker form of bridging Olympic capital than the live attendees. Nevertheless, they perceive the symbolic and informational content, which may or may not result in action that is maintained only by linking structures of the media (e.g., comments via social media). In the model, this form of weak bridging capital is called broadcast Olympic capital. It can be however converted into live Olympic capital if there is a personal experience that identifies the observed message as credible and confirms beliefs.

Opposed to the social capital created by live attendance, broadcast Olympic capital is centred in the mentioned field of tensions between the social and economic logic dependent to the agenda-setting of the media. More importantly, broad- casting revenue is by far the largest component of the Olympic turnover and remains with the IOC whereas the ticketing revenues are left for the OCOG (IOC, 2017; Preuss, 2004). It is therefore not surprising that the business focus of the Olympic Games has become the selling of media rights, downgrading the live event to a media content and figurehead to construct brand awareness for the Olympic movement (Maguire, Butler, Barnard, \& Golding, 2008; Nickisch, 2016). Therefore, broadcast Olympic capital is subject to a communicated reality that may be distorted by the media coverage and could result in likewise distorted memories (Tversky \& Kahneman, 1973).

Testable propositions. The modelling of Olympic capital discussed in this section and depicted in Figures 1 and 2 provided a number of testable propositions. In particular, the mechanisms of Olympic capital creation were argued in much more detail than in the previous literature. Moreover, sound statements were derived on the causalities of Olympic capital formation. However, the whole complexity of the theoretical modelling cannot be expected to be captured in one coherent empirical approach. Notwithstanding, the remainder of this article addresses at least some basic tests of the key propositions to illustrate the empirical plausibility of the model. The following two propositions are selected for this early evidence of the developed theory:

Proposition 1: The Olympic capital created by Olympic values among live spectators is higher than that among broadcast spectators;

Proposition 2: A higher intensity of emotional exposure and a positive environment result in higher Olympic capital.

\section{Methods and data}

The data used for the empirical tests to be presented in the next section were gathered by a cluster sampling $(N=1,703)$ of two surveys of live spectators at Olympic events and one survey of broadcast spectators. For the first cluster $(N=243)$, live spectators at the Winter YOG, held from 12 to 21 February 2016 in Lillehammer, Norway, were surveyed (IOC, 2016b). The second cluster $(N=1,118)$ of broadcast spectators was drawn from non-sporting-event occasions in a medium-sized German town (Bayreuth, Northern Bavaria) during the run-up to the 2016 Summer Olympic Games. The third cluster $(N=342)$ was sampled among live spectators at the Summer Olympic Games staged from 5 to 21 August 2016 in Rio de Janeiro, Brazil (IOC, 2016a). As a self-motivated study, the surveys were free of any heteronomous interests but had to cope with limited funding. Therefore, a cost-effective and still statistically viable sampling procedure was chosen. It is a purposeful, multistage cluster sampling that sufficiently captures control groups for the research aim. Such a sampling is recommended when the distribution of the studied subject in the population is unknown and will be approximately representative with rising sample size ( $\mathrm{Li}$, Pitts, \& Quarterman, 2008). 
However, representativeness is not a major concern of this research given that the relationship between the measured constructs is in the centre of interest and because a control group design helps to detect the relevant relationships (Jones, 2015). More important according to the theoretical model was to capture different environments of Olympic capital creation influencing spectator perception. In this regard, the Winter YOG in Lillehammer can be qualified as a very positive environment for conveying Olympic values. The event built upon the legacy of the 1994 Winter Olympic Games, which is seen as one of the best Winter Games ever (IOC, 2016c; Owen, 2014). The new and more modest format of the YOG is moreover argued as a particularly suitable platform for conveying Olympic values (Prüschenk \& Kurscheidt, 2017).

In contrast, the intensity of the emotional exposure is lower than that found at the much larger 2016 Summer Olympic Games in Rio de Janeiro, while the environment of those Games was partially described as the worst ever (Gibson, 2014). The city and the country were suffering from various social, economic and political problems at the time. Cost over-runs, corruption scandals, safety and pollution issues overshadowed the event. In addition, health risks caused by a Zika virus epidemic frightened the athletes and visitors (Phillips, 2016). Thus, the question arises whether Olympic capital is still generated under such circumstances. Finally, the German sample of broadcast spectators was gathered between 1 and 29 July 2016 shortly before the Rio Games. Therefore, respondents might have been influenced by controversial media coverage. However, at the same time, the awareness of broadcast spectators for the Games was generally given due to the public debate on the Olympics ahead of the event.

All surveys were conducted by direct social contact with survey assistants and on a self-administered, paper-pencil basis. This procedure represents a reliable sampling and forces control of every questionnaire during data entry. Thus, invalid or dubious responses are easily detected (Li et al., 2008). The questionnaire was available in German, English and Portuguese to facilitate understanding and took approximately 10 minutes for the respondents. It was designed as a multipurpose instrument asking questions on the perception of Olympic values and item batteries on attitudes towards social, economic and political issues of the Games and the Olympic movement. Sociodemographic characteristics closed the questionnaire. For the measurement, 5-point Likert scales ( $1=$ 'disagree' to $5=$ 'agree'), partly complemented by the choice 'don't know' (=0), were applied (Jones, 2015). With regard to statistical validity and efficiency, 5-point Likert scales have been shown in recent methods research to be equivalent to larger scales and have the advantage of being very intuitive (Revilla, Saris, \& Krosnick, 2014; Wakita, Ueshima, \& Noguchi, 2012).

Since the purpose of the data analysis in this article is simply to illustrate the plausibility of the developed model in relation to the above raised Propositions 1 and 2, it is sufficient to focus on the perception of Olympic values as a measure of Olympic capital. The following two variables are relevant:
(1) VALUESIMP measures whether the respondents think that Olympic values are important at the Olympic Games $(0=$ 'don't know' to 5='agree'), and (2) OLYMPVALUES represents the mean of eleven values associated with the Olympic Games ( $1=$ 'disagree' to 5='agree'; excellence, respect, friendship, dialogue, diversity, tolerance, fair play, solidarity, development, peace and inspiration; Cronbach's $\alpha=.87)$. Both empirical constructs were related to binary variables ( $1=y e s, 0=$ no) representing the three surveys and, thus, testing for differences in the perceptions of live spectators at the Rio Olympics (RIOLIVE) versus live spectators at the YOG (LILLELIVE) and (German) broadcast spectators (GERMRIOTV). Descriptives, analyses of variance, correlations and regressions, without considering control variables (Jones, 2015; Wooldridge, 2013), were applied using Stata/SE 13.1.

\section{Empirical Results}

\section{Descriptive Statistics and Hypothesis Testing}

Table 1 presents the descriptive statistics. It can be observed that VALUESIMP has a high overall mean, which is obviously driven by the general interest of all three spectator groups in the Olympic Games. As expected, the highest mean is found among the live spectators of the Rio Olympics, which is closely followed by the attendees of the YOG. The broadcast spectators rate considerably lower. Still, they are affirmative on average. This finding is the first indication that substantial bridging Olympic capital is observable and that Proposition 1 that Olympic capital among live spectators is greater than that among broadcast spectators is plausible. Moreover, the average score of Rio visitors exceeds that of the YOG attendees, who presumably exhibit less emotional exposure due to the smaller nature of the event, which features less known young athletes. In addition, the Rio live spectators attended the established platform or symbol of the Olympic idea, and thus, the question of the importance of Olympic values at the Games was closer to their current experience.

However, regarding OLYMPVALUES, the result is not confirmed. Here, the YOG attendees show slightly higher rates on average than the visitors of the Rio Olympics, while the TV viewers again rate the lowest. Here, the positive environment of the YOG may come into play. It may also be that people attending the less prestigious YOG tend to be more value oriented in general, while the Rio visitors instead seek outstanding entertainment at an event of global esteem.

However, the standard deviation of the live spectators of the YOG is slightly higher than that of those at the Rio Summer Games. Therefore, the question arises of whether the descriptive evidence holds in inference testing. A Kruskal-Wallis test will disclose whether or not the three samples differ in Olympic capital. Indeed, both for VALUESIMP, $X^{2}(2, N=1,691)=90.6$, $p<.001$, and OLYMPVALUES, $X^{2}(2, N=1,529)=416, p<.001$, the samples are found to be significantly different. However, Dunn and Conover-Iman tests, respectively, prove that the findings 
Table 1. Descriptive results on Propositions 1 and 2.

\begin{tabular}{|c|c|c|c|c|c|c|c|c|}
\hline Sample & \multicolumn{4}{|c|}{ VALUESIMP } & \multicolumn{4}{|c|}{ OLYMPVALUES } \\
\hline Rio Summer Games 2016 live spectators & 4.45 & 0.91 & 5 & 339 & 4.21 & 0.54 & 4.27 & 292 \\
\hline Total sample & 4.05 & 1.16 & 4 & 1,691 & 3.74 & 0.73 & 3.82 & 1,529 \\
\hline
\end{tabular}

Notes: VALUESIMP stands for the variable ( $0=$ 'don't know' to $5=$ 'agree') on the item 'Olympic values' within the item battery 'How important are the following aspects for Olympic Games?'. OLYMPVALUES stands for the mean of eleven values associated with the Olympic Games ( $1=$ 'disagree' to $5=$ 'agree'; excellence, respect, friendship, dialogue, diversity, tolerance, fair play, solidarity, development, peace and inspiration; Cronbach's $\mathrm{a}=.87$ ).

are clearly dominated by the consistently lower ratings of the broadcast spectators, whereas the two groups of live spectators do not significantly differ (for VALUESIMP, $z=1.29, p=.30$, and for OLYMPVALUES, $z=-1.48, p=.21$, in the Conover-Iman tests with Bonferroni adjustment).

The hierarchy among the three samples found in the descriptive statistics is maintained, with the Rio visitors yielding the highest average rank $(1,021)$ for VALUESIMP in the KruskalWallis test, followed by the YOG attendees (973), while the opposite is true for OLYMPVALUES $(1,120$ versus 1,070$)$. Hence, Proposition 1 that Olympic capital among live spectators tends to be higher than that among broadcast spectators is confirmed. However, the findings on the emotional exposure and environment, when comparing the two groups of live spectators (Proposition 2), are mixed with regard to the different constructs of Olympic values. Therefore, the differences between the Rio visitors and YOG attendees (by LILLELIVE) should be examined for the subsample of live spectators. Mann-Whitney $U$ tests between the two live spectator groups reveal that they are significantly different for OLYMPVALUES, $z=-2.60, p<.01, r=-.07$, but not for VALUESIMP, $z=1.32, p=.19, r=.05$. Thus, further data analyses on the full sample are needed.

\section{Correlation and Regression Analysis}

The Spearman rank correlations shown in Table 2 reveal high significances throughout and a consistently stronger positive relationship between the proxies for Olympic capital and RIOLIVE compared with LILLELIVE. In contrast, GERMRIOTV is negatively correlated with VALUESIMP, documenting a distinct difference from the live spectators because RIOLIVE and LILLELIVE are positively linked to the value construct. Regarding

Table 2. Rank correlation and regression results on Propositions 1 and 2.

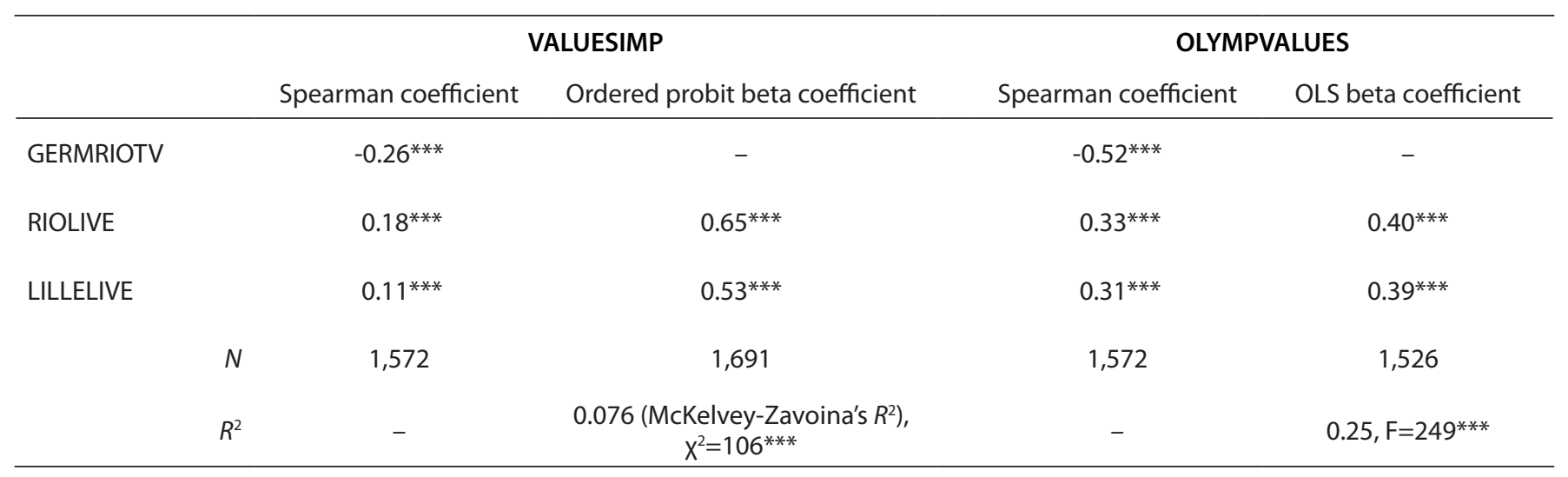

Notes: VALUESIMP stands for the variable ( $0=$ 'don't know' to $5=$ 'agree') on the item 'Olympic values' within the item battery 'How important are the following aspects for Olympic Games?'. OLYMPVALUES stands for the mean of eleven values associated with the Olympic Games ( $1=$ 'disagree' to $5=$ 'agree'; excellence, respect, friendship, dialogue, diversity, tolerance, fair play, solidarity, development, peace and inspiration; Cronbach's a=.87). GERMRIOTV, RIOLIVE and LILLELIVE stand for binary variables ( $1=$ yes, $0=$ no), controlling for the three cluster surveys of German broadcast spectators of the Rio Summer Games 2016 , live spectators at the Rio Summer Games 2016 and live spectators at the Lillehammer YOG 2016, respectively. The significance levels are * $p<0.05$, ${ }^{* *} p<$ 0.01 , *** $p<0.001$. 
OLYMPVALUES, the gap between the effect size of GERMRIOTV and those of RIOLIVE and LILLELIVE is accentuated, while the results of the live spectators are closer. Hence, in contrast to the previous evidence, the Rio visitors now appear to exhibit significantly more Olympic capital than the YOG attendees, which may be attributed to a more intense emotional exposure at the larger Rio Olympics. Moreover, the findings are robust based on the Pearson correlations, indicating that parametric regression analyses of the constructs of Olympic capital towards RIOLIVE and LILLELIVE as explanatory variables (i.e., the broadcast group represents the base estimation) are expected to yield meaningful results.

Since VALUESIMP is a Likert-scaled variable, ordered probit or logit models must be applied (Wooldridge, 2013). In the probit regression shown in Table 2, RIOLIVE again has a significantly stronger effect on VALUESIMP than LILLELIVE. However, although the regression is significant, the model fit is weak without further control variables. Nevertheless, the finding that RIOLIVE explains VALUESIMP slightly better than LILLELIVE is also documented by the higher average change in the probabilities of 0.085 versus 0.069 as predicted by the probit model. In addition, the results are robust, both in an ordered logit model and in regressions on a binary variant of VALUESIMP accentuating affirmative answers ( $1=$ 'agree' and 'somewhat agree', $0=$ otherwise). Hence, the higher explanatory power of RIOLIVE in causal regression models underlines the correlation findings.

Finally, this is also tested for OLYMPVALUES in the OLS regression shown in Table 2, which yields a high explanation of variance, given that no control variables are considered in this simple modelling. Again, it is confirmed that the marginal effect of RIOLIVE on OLYMPVALUES is slightly higher than the predictor of LILLELIVE. Thus, in both the correlation and regression analyses, it is found that the Rio visitors rate Olympic values significantly higher than the YOG attendees, further proving the relevance of emotional exposure as stated in Proposition 2. However, the difference in Olympic capital evidenced by the two live spectator groups is marginal. Consequently, the results may change when controlling for confounders, which could strengthen the impact of the positive environment at the Lillehammer YOG on the perception of Olympic values. Hence, the results presented here for Proposition 2 are not conclusive in terms of whether emotional exposure has a stronger effect on Olympic capital than a positive environment or vice versa.

\section{Discussion and Conclusion}

The Olympic movement and its primary product, the Olympic Games, benefit from the value foundation of Olympism (Coubertin, 2000), which is unique in the global sports world. This not only fosters the brand of the Olympic rings and customer loyalty (Davis, 2012; Seguin et al., 2008) but is also the starting point of social capital creation through the Olympic key values of respect, friendship and excellence. Along the perception, simultaneous experience and cultural practice of the
Olympic values, they are transformed from the individual level to a collective level and, thus, form bonding and bridging social capital (Bourdieu, 1986; Putnam, 2000), particularly among Olympic athletes and spectators. At that point of the process, the commodification of the Olympic value of excellence leverages Olympic capital via extensive global media coverage and supplements linking social capital in the economic and political sphere.

At the same time, this phase is fraught with tensions due to the diverging logics of social and professional interactions and may also cause erosion of the Olympic capital. In this context, it is crucial that the largest Olympic stakeholder group of the worldwide spectatorship is effectively reached by the Olympic message. It was argued that live spectators run through a cycle of shared simultaneous experiences, resulting in an episodic memory of Olympic values that is stronger and more sustainable than the semantic memory developed by broadcast spectators based on dichotomous observation. Additionally, the perception of Olympic values by the latter may be distorted by information selection and media coverage. However, for both spectator groups, the length and intensity of the emotional exposure is a moderating variable. This reasoning was depicted in two graphical models, proposing notably that live Olympic capital is larger than broadcast Olympic capital (Proposition 1). Then, the propositions were tested using data collected from three surveys of German broadcast spectators of the 2016 Rio Summer Olympics, live attendees at those Games and visitors to the 2016 Lillehammer Winter YOG. Moreover, the two latter samples enabled an examination of Proposition 2 concerning emotional exposure and environment when comparing the live spectator groups at the large Summer Games with those at the smaller, less prestigious Olympic event format.

First, the empirical results overall showed a high appreciation of the Olympic values and, thus, documented considerable Olympic capital. Second, Proposition 1 was clearly confirmed that live spectators exhibit a significantly larger Olympic capital than broadcast spectators. Third, it was found that the Rio visitors rate Olympic values significantly higher than YOG attendees do (Proposition 2). However, the difference in Olympic capital between the two live spectator groups is marginal. The higher Olympic capital for Rio visitors may be attributed to the more intense emotional exposure at the Olympic Games, while the small difference may be explained by the positive environment of the YOG in Lillehammer or the more value-oriented spectatorship at the modest event format (Prüschenk \& Kurscheidt, 2017).

However, the empirical study did not control for confounding effects in either the individual and social dimensions or the economic and political dimensions of Olympic capital creation. For instance, preferences for sport and the Olympics, motives for visiting the event, attitudes towards the governance of the Olympic Games and the Olympic movement as well as sociodemographics can be expected to influence the perception of the Olympic values. Thus, more sophisticated, multiple regression models should be tested on the data to examine the incremen- 
tal effect of emotional exposure and the environment (Proposition 2). The evidence might lead to different conclusions on the two constructs.

However, this follow-up research will benefit from the theory concerning the process and causalities of Olympic capital creation developed in this article. Such detailed reasoning on the formation of social capital on the basis of the Olympic values was missing in the previous literature. Moreover, the theoretical determinants and structure of the model may be generalisable to other areas of social capital creation, in sports and beyond. In addition to empirically studying Propositions 1 and 2, two further theoretical insights are notable. First, the commercialisation of the Olympic Games is not necessarily detrimental to Olympic capital creation because in particular, the media coverage also contributes to the global dissemination of Olympic values. The relevant question is how well the commercialisation - as the commodification of the Olympic value of excellence - is governed and balanced with the conveyance of other Olympic values (i.e., respect and friendship). Second, the lower Olympic capital creation among broadcast spectators compared to the live attendees may be leveraged.

The aim of a strategic event leveraging approach should be to interlink the semantic memory of TV viewers and the episodic memory of live spectators and other highly involved stakeholder groups. The lack of personal exchange could be compensated by accompanying communication to build a global bridge. According to media richness theory, complex contents require complex transmitters (Robert \& Dennis, 2005). In particular, stable relationships with trustworthy media partners ought to be developed to generate lasting effects for the conveyance of Olympic values (Hall \& Widén-Wulff, 2008; Lee \& Maguire, 2009). Life-long learning through a constant exchange of values and information could generate not only Olympic capital but also an investment in business development (Biesta, 2006; Field, 2005). A positive perception has a definitively stronger impact on the willingness to apply experience and take selfactions (Biscaia, Correia, Rosado, Maroco, \& Ross, 2012).

In future research, these considerations may be further developed theoretically, and effective governance models and management strategies should be identified. Moreover, the topic still warrants empirical work regarding diverse issues, which may be guided by the presented model. In this article, the purpose of the data analysis was simply to illustrate the plausibility of the model. To address the statistical limitations of this early evidence beyond the mentioned multivariate analyses, further sampling is needed. Larger surveys with a more culturally and statistically diverse population should be conducted. If and where possible, representative samples would be highly desirable, though they are difficult and costly to construct. Improved evidence will certainly contribute to an explorative refinement of the deductive model discussed here. Ultimately, future modelling and findings will lead to more tangible policy and management implications, whereas the present article focussed on a basic theoretical understanding of Olympic capital creation.

\section{Funding}

The publication of this research was supported by the German Research Foundation (DFG) and the University of Bayreuth within the funding programme for Open Access Publishing.

\section{Competing Interests}

The authors have declared that no competing interests exist.

\section{Data Availability Statement}

All relevant data are within the article.

\section{References}

Andorfer, V. A. (2013). Ethical consumption in Germany. A crosssectional analysis of determinants of fair trade consumption (200-2010). Zeitschrift für Soziologie, 42(5), 424-443. doi: 10.1515/zfsoz-2013-0505

Atkinson, R. C., \& Wickens, T. D. (1971). Human memory and the concept of reinforcement. In R. Glaser (Ed.), The nature of reinforcement: Part I (pp. 99-186). Pittsburgh: University Learning Research and Development Center.

Barnett, C., Cloke, P., Clarke, N., \& Malpass, A. (2005). Consuming ethics: Articulating the subjects and spaces of ethical consumption. Antipode, 37(1), 23-45. doi: 10.1111/j.00664812.2005.00472.x

Berkes, F. (2008). Commons in a multi-level world. International Journal of the Commons, 2(1), 1-6. doi: 10.18352/ijc.80

Biesta, G. (2006). What's the point of lifelong learning if lifelong learning has no point? On the democratic deficit of policies for lifelong learning. European Educational Research Journal, 5(3/4), 169-180. doi: 10.2304/eerj.2006.5.3.169

Biscaia, R., Correia, A., Rosado, A., Maroco, J., \& Ross, S. (2012). The effects of emotions on football spectators' satisfaction and behavioural intentions. European Sport Management Quarterly, 12(3), 227-242. doi: 10.1080/16184742.2012.679949

Black, D. (2007). The symbolic politics of sport mega-events: 2010 in comparative perspective. Politikon, 34(3), 261-276. doi: 10.1080/02589340801962536

Blau, P. M. (1964). Exchange and power in social life. New York, NY: John Wiley.

Block, F., \& Polanyi, K. (2003). Karl Polanyi and the writing of the great transformation. Theory and Society, 32(3), 275-306. doi: 10.1023/a:1024420102334

Bouchet, P., Bodet, G., Bernache-Assollant, I., \& Kada, F. (2011). Segmenting sport spectators: Construction and preliminary validation of the Sporting Event Experience Search (SEES) scale. Sport Management Review, 14(1), 42-53. doi: 10.1016/j.smr.2010.02.001 
Bourdieu, P. (1984). Distinction: A social critique of the judgement of taste. Cambridge, MA: Harvard University Press.

Bourdieu, P. (1986). The forms of capital. In J. G. Richardson (Ed.), Handbook of theory and research for the sociology of education (pp. 241-258). New York, NY: Greenwood Publishing.

Brandes, P., Dharwadkar, R., \& Wheatley, K. (2004). Social exchanges within organizations and work outcomes: The importance of local and global relationships. Group \& Organization Management, 29(3), 276-301. doi: $10.1177 / 1059601103257405$

Broadbent, D. E. (1963). Flow of information within the organism. Journal of Verbal Learning and Verbal Behavior, 2(1), 34-39. doi: 10.1016/s0022-5371(63)80065-1

Burt, R. S. (1997). The contingent value of social capital. Administrative Science Quarterly, 42(2), 339-365. doi: $10.2307 / 2393923$

Chalip, L. (2006). Towards social leverage of sport events. Journal of Sport \& Tourism, 11(2), 109-127. doi: $10.1080 / 14775080601155126$

Christesen, P. (2015). Pulling the pieces together: Social capital and the Olympics, ancient and modern. Society for Classical Studies. Retrieved from https://classicalstudies.org/annualmeeting/147/abstract/pulling-pieces-together-social-capital-and-olympics-ancient-and-modern

Christiansen, A. V. (2010). 'We are not sportsmen, we are professionals': Professionalism, doping and deviance in elite sport. International Journal of Sport Management and Marketing, 7(1/2), 91-103. doi: 10.1504/IJSMM.2010.029714

Coalter, F. (2008). Sport-in-development: Development for and through sport? In M. Nicholson \& R. Hoye (Eds.), Sport and social capital (pp. 39-68). Oxford: Butterworth-Heinemann.

Coase, R. (1998). The new institutional economics. American Economic Review, 88(2), 72-74.

Coleman, J.S. (1990). Foundations of social theory. Cambridge, MA: Harvard University Press.

Conway, M. A. (1997). The inventory of experience: Memory and identity. In J. W. Pennebaker, D. Paez, \& B. Rimé (Eds.), Collective memory of political events: Social psychological perspectives (pp. 21-45). New Jersey: Lawrence Erlbaum Associates.

Cook, K. S., \& Rice, E. (2003). Social exchange theory. In J. Delamater (Ed.), Handbook of social psychology (pp. 53-76). New York: Kluwer Academic/Plenum Publishers.

Crawford, G. (2004). Consuming sport: Fans, sport and culture. International Journal of Sports Marketing and Sponsorship, 6(2), 47-62. doi: 10.1108/ijsms-06-02-2004-b007.

Coubertin, P. de (2000). Olympism. Selected writings. In N. Müller (Ed.), Olympism. Selected writings (pp. 51-751). Lausanne: International Olympic Committee.

Dauvergne, P., \& Lister, J. (2012). Big brand sustainability: Governance prospects and environmental limits. Global Environmental Change, 22(1), 36-45. doi: 10.1016/j.gloenvcha.2011.10.007

Davis, J. A. (2012). The Olympic Games effect: How sports marketing builds strong brands. Singapore: John Wiley \& Sons.
Digel, H. (2008). The risks of the Youth Olympic Games. Viewpoint, 23(3), 53-58.

Downward, P., Pawlowski, T., \& Rasciute, S. (2014). Does associate behaviour raise social capital? A cross-country analysis of trust. Eastern Economic Journal, 40(2), 150-165. doi: 10.1057/eej.2013.26

Emerson, R. M. (1976). Social exchange theory. Annual Review of Sociology, 2(1), 335-362. doi: 10.1146/annurev. so.02.080176.002003

Esser, H. (1999). Soziologie: Allgemeine Grundlagen [Foundations of sociology] ( $3^{\text {rd }}$ ed.). Frankfurt a.M.: Campus.

Ferrand, A., \& Pages, M. (1999). Image management in sport organisations: The creation of value. European Journal of Marketing, 33(3/4), 387-402. doi: 10.1108/03090569910253224

Field, J. (2005). Social capital and lifelong learning. Bristol: Policy Press.

First, S. (2017). Integrating social capital theory in social exchange theory. Retrieved from https://owlcation.com/social-sciences/Integrating-Social-Capital-and-Social-Exchange-Theory

Fisher, K. E., \& Naumer, C. M. (2006). Information grounds: Theoretical basis and empirical findings in information flow in social settings. In A. Spink \& C. Cole (Eds.), New directions in human information behavior (pp. 93-111). Dordrecht: Springer.

Gibson, O. (2014). Rio 2016 Olympic preparations damned as 'worst ever' by IOC. Retrieved from https://www.theguardian.com/sport/2014/apr/29/rio-2016-olympic-preparations-worst-ever-ioc

Giulianotti, R. (2005). Sport spectators and the social consequences of commodification: Critical perspectives from Scottish football. Journal of Sport and Social Issues, 29(4), 386-410. doi: 10.1177/0193723505280530

Glenberg, A. M. (1997). What memory is for. Behavioral and Brain Sciences, 20(1), 1-19. doi: 10.1017/S0140525X97470012

Granovetter, M. S. (1973). The strength of weak ties. American Journal of Sociology, 78(6), 1360-1380. doi: 10.1086/225469

Green, C., \& Chalip, L. (2004). Paths to volunteer commitment: Lessons from the Sydney Olympic games. In R. A. Stebbins \& M. Graham (Eds.), Volunteering as leisure/leisure as volunteering: An international assessment (pp. 49-67). Wallingford: CABI.

Grix, J., \& Carmichael, F. (2012). Why do governments invest in elite sport? A polemic. International Journal of Sport Policy and Politics, 4(1), 73-90. doi: 10.1080/19406940.2011.627358

Grix, J., \& Houlihan, B. (2014). Sports mega-events as part of a nation's soft power strategy: The cases of Germany (2006) and the UK (2012). British Journal of Politics \& International Relations, 16(4), 572-596. doi: 10.1111/1467-856X.12017

Groeneveld, M. M., Houlihan, B., \& Ohl, F. (2011). Social capital and sport governance in Europe. New York, London: Routledge.

Hall, H., \& Widén-Wulff, G. (2008). Social exchange, social capital and information sharing in online environments: Lessons from three case studies. In M.-L. Huotari \& E. Davenport 
(Eds.), From information provision to knowledge production (pp. 73-86). Oulu: University of Oulu.

Hofer, M., Reinders, H., \& Fries, S. (2010). Wie sich die Werte ändern [How values change]. Zeitschrift für Entwicklungspsychologie und pädagogische Psychologie, 42(1), 26-38. doi: 10.1026/0049-8637/a000003

Homans, G. C. (1961). Social behavior: Its elementary forms. New York: Harcourt, Brace \& World.

Horbel, C., Popp, B., Woratschek, H., \& Wilson, B. (2016). How context shapes value co-creation: Spectator experience of sport events. Service Industries Journal, 36(11-12), 510-531. doi: 10.1080/02642069.2016.1255730

Houlihan, B. (2012). Sport policy convergence: A framework for analysis. European Sport Management Quarterly, 12(2), 111135. doi: 10.1080/16184742.2012.669390

Houlihan, B., \& Green, M. (2008). Comparative elite sport development: Systems, structures and public policy. Oxford: Butterworth-Heinemann.

Houlihan, B., \& Zheng, J. (2013). The Olympics and elite sport policy:Where will it all end? International Journal of the History of Sport, 30(4), 338-355. doi: 10.1080/09523367.2013.765726

Inglehart, R., \& Baker, W. E. (2000). Modernisation, cultural change, and the persistence of traditional values. American Sociological Review, 65(1), 19-51. doi: 10.2307/2657288

International Olympic Committee. (2013). Olympism and the Olympic movement (3rd ed.). Lausanne: The Olympic Museum.

International Olympic Committee. (2014). Athletes: At the heart of the Olympic movement. Retrieved from https://stillmed. olympic.org/Documents/IOC_Executive_Boards_and_Sessions/IOC_Sessions/126_Session_Sochi/Olympic_Agenda2020_Part_2_English.pdf

International Olympic Committee. (2015). Olympic charter. Lausanne: International Olympic Committee.

International Olympic Committee. (2016a). IOC annual report 2015: Credibility, sustainability and youth. Lausanne: International Olympic Committee.

International Olympic Committee. (2016b). Lillehammer 2016 -the official report of the 2nd Winter Youth Olympic Games. Lillehammer, Norway: International Olympic Committee.

International Olympic Committee. (2016c). Lillehammer 2016 celebrates one-year-on successes while athletes set sights on Pyeongchang 2018. Lillehammer, Norway: International Olympic Committee.

International Olympic Committee. (2017b). Revenue sources and distribution. Olympic Marketing Revenues. Retrieved from https://www.olympic.org/ioc-financing-revenue-sourcesdistribution

Jones, I. (2015). Research methods for sports studies. Abington, UK: Routledge.

Kavetsos, G., \& Szymanski, S. (2010). National well-being and international sports events. Journal of Economic Psychology, 31(2), 158-171. doi: 10.1016/j.joep.2009.11.005

Koenigstorfer, J., Bocarro, J. N., Byers, T., Edwards, M. B., Jones, G. J., \& Preuss, H. (2019). Mapping research on legacy of mega sporting events: Structural changes, consequences, and stakeholder evaluations in empirical studies. Leisure Studies, 38(6), 729-745. doi: 10.1080/02614367.2019.1662830

Koo, G.-Y., \& Hardin, R. (2008). Difference in interrelationship between spectators' motives and behavioral intentions based on emotional attachment. Sport Marketing Quarterly, 17(1), 30-43.

Kurscheidt, M., \& Prüschenk, N. (2020). Attitudes toward Olympic gigantism: Evidence from Germany. German Journal of Exercise and Sport Research. doi: 10.1007/s12662-01900642-w

Lee, J. W., \& Maguire, J. (2009). Global festivals through a national prism. International Review for the Sociology of Sport, 44(1), 5-24. doi: 10.1177/1012690208101483

Leik, R. K. (1992). New directions for network exchange theory: Strategic manipulation of network linkages. Social Networks, 14(3), 309-323. doi: 10.1016/0378-8733(92)90007-T

Li, M., Pitts, B. G., \& Quarterman, J. (2008). Research methods in sport management. Morgantown, WV: Fitness Information Technology.

Lindstrom, M., Hanson, B. S., \& Ostergren, P. O. (2001). Socioeconomic differences in leisure-time physical activity: The role of social participation and social capital in shaping health related behaviour. Social Science \& Medicine, 52(3), 441-451. doi: 10.1016/S0277-9536(00)00153-2

MacKenzie (1986). The role of attention in mediating the effect of advertising on attribute importance. Journal of Consumer Research, 13(2), 174-195. doi: 132.180.100.52

Mack, A., \& Rock, I. (1998). Inattentional blindness: Perception without attention. In R. D. Wright (Ed.), Visual attention (pp. 55-76). New York, Oxford: Oxford University Press.

Maguire, J., Butler, K., Barnard, S., \& Golding, P. (2008). Olympism and consumption: An analysis of advertising in the British media coverage of the 2004 Athens Olympic Games. Sociology of Sport Journal, 25(2), 167-186. doi: 10.1123/ ssj.25.2.167

Mehus, I. (2005). Distinction through sport consumption. International Review for the Sociology of Sport, 40(3), 321-333. doi: doi:10.1177/1012690205060159

Minnaert, L. (2012). An Olympic legacy for all? The noninfrastructural outcomes of the Olympic Games for socially excluded groups (Atlanta 1996-Beijing 2008). Tourism Management, 33(2), 361-370. doi: 10.1016/j.tourman.2011.04.005

Misener, L., \& Mason, D. S. (2006). Creating community networks: Can sporting events offer meaningful sources of social capital? Managing Leisure, 11(1), 39-56. doi: 10.1080/13606710500445676

Mohr, J. J., \& Sohi, R. S. (1996). Communication flows in distribution channels: Impact on assessments of communication quality and satisfaction. Journal of Retailing, 71(4), 393-415. doi: 10.1016/0022-4359(95)90020-9

Morley, D., \& Robins, K. (2002). Spaces of identity: Global media, electronic landscapes and cultural boundaries. London: Routledge. 
Mouw, T. (2006). Estimating the causal effect of social capital: A review of recent research. Annual Review of Sociology, 32(1), 79-102. doi: 10.1146/annurev.soc.32.061604.123150

Nagy, Z. I. (2011). The unique features of the financing of professional football. Public Finance Quarterly, 56(4), 539-552.

Nicholson, M., \& Hoye, R. (2008). Sport and social capital. Oxford: Butterworth-Heinemann.

Nickisch, C. (2016). The Olympics needs a new business model. Retrieved from https://hbr.org/2016/08/the-olympicsneeds-a-new-business-model

Olney, T. J., Holbrook, M. B., \& Batra, R. (1991). Consumer responses to advertising: The effects of ad content, emotions, and attitude toward the ad on viewing time. Journal of Consumer Research, 17(4), 440. doi: 10.1086/208569

Owen, D. (2014). Lillehammer 1994 showed that size isn't everything in the Olympic world. Retrieved from http:// www.insidethegames.biz/articles/1018424/lillehammer1994-showed-that-size-isn-t-everything-in-the-olympicworld

Payne, M. (2006). Olympic turnaround: How the Olympic Games stepped back from the brink of extinction to become the world's best known brand. London: Praeger Publishers.

Phillips, D. (2016). What is Rio's Olympic legacy? Retrieved from https://www.theguardian.com/world/2016/dec/20/whatis-rio-olympic-legacy-brazil

Preuss, H. (2004). The economics of staging the Olympics. A comparison of the Games, 1972-2008. Cheltenham, UK: Elgar.

Preuss, H. (2007a). The conceptualisation and measurement of mega sport event legacies. Journal of Sport \& Tourism, 12(34), 207-228. doi: 10.1080/14775080701736957

Preuss, H. (2007b). Impact and evaluation of major sporting events. European Sport Management Quarterly, 6(4), 313316. doi: 10.1080/16184740601154441

Preuss, H. (2019). Event legacy framework and measurement. International Journal of Sport Policy and Politics, 11(1), 103118.

Prüschenk, N., \& Kurscheidt, M. (2017). Do the Youth Olympic Games have the potential to shift perceptions of Olympism? Evidence from young people's views on Olympic values. International Journal of Sport Management and Marketing, 17(4/5/6), 351-380. doi: 10.1504/IJSMM.2017.10008117

Putnam, R. D. (2000). Bowling alone: The collapse and revival of American community. New York: Simon \& Schuster.

Rensink, R. A., O'Regan, J. K., \& Clark, J. J. (1997). To see or not to see: The need for attention to perceive changes in scenes. Psychological Science, 8(5), 368-373. doi: 10.1111/j.14679280.1997.tb00427.x

Revilla, M. A., Saris, W. E., \& Krosnick, J. A. (2014). Choosing the number of categories in agree-disagree scales. Sociological Methods \& Research, 43(1), 73-97. doi: 10.1177/0049124113509605

Robert, L., \& Dennis, A. R. (2005). Paradox of richness: A cognitive model of media choice. IEEE Transactions on Professional Communication, 48(1), 10-21. doi: 10.1109/tpc.2004.843292
Schnitzer, M., Walde, J., Scheiber, S., Nagiller, R., \& Tappeiner, G. (2018). Do the Youth Olympic Games promote Olympism? Analysing a mission (im)possible from a local youth perspective. European Journal of Sport Science, 18(5), 722-730. doi: 10.1080/17461391.2018.1458906

Schnitzer, M., Walde, J., Scheiber, S., Nagiller, R., \& Tappeiner, G. (2019). Does the young residents' experience with the Youth Olympic Games influence the support for staging the Olympic Games? Tourism Management Perspectives, 30, 220-231. doi: 10.1016/j.tmp.2019.03.002

Schulenkorf, N. (2009). An ex ante framework for the strategic study of social utility of sport events. Tourism and Hospitality Research, 9(2), 120-131. doi: 10.1057/thr.2009.2

Schulenkorf, N. (2010). Bridging the divide. The role of sport events in contributing to social development between disparate communities. Göttingen: Sierke.

Schulenkorf, N. (2012). Sustainable community development through sport and events: A conceptual framework for sport-for-development projects. Sport Management Review, 15(1), 1-12. doi: 10.1016/j.smr.2011.06.001

Schulenkorf, N., \& Edwards, D. (2012). Maximizing positive social impacts: Strategies for sustaining and leveraging the benefits of intercommunity sport events in divided societies. Journal of Sport Management, 26(5), 379-390. doi: 10.1123/jsm.26.5.379

Schuller, T., \& Field, J. (1998). Social capital, human capital and the learning society. International Journal of Lifelong Education, 17(4), 226-235. doi: 10.1080/0260137980170402

Séguin, B., Richelieu, A., \& O'Reilly, N. (2008). Leveraging the Olympic brand through the reconciliation of corporate and consumers' brand perceptions. International Journal of Sport Management and Marketing, 3(1/2), 3-22. doi: 10.1504/ ijsmm.2008.015958

Shaw, C. A. (2008). Five ring circus: Myths and realities of the Olympic Games. Gabriola Islands: New Society Publishers.

Silk, M., Andrews, D. L., \& Cole, C. L. (2005). Corporate nationalism(s): The spatial dimensions of sporting capital. In M. L. Silk, D. L. Andrews, \& C. L. Cole (Eds.), Sport and corporate nationalisms (pp. 1-13). Oxford: Berg.

Simon, H. A., \& Newell, A. (1964). Information processing in computer and man. American Scientist, 52(3), 281-300.

Simons, D. J. (2000). Current approaches to change blindness. Visual Cognition, 7(1/3), 1-15. doi: 10.1080/135062800394658

Simons, I. (2015). How to slay a dragon slowly: Applying slow principles to event design. In G. Richards, L. Marques, \& K. Mein (Eds.), Event design: Social perspectives and practices (pp. 78-91). London: Routledge.

Skinner, B. F. (1948). Superstition in the pigeon. Journal of Experimental Psychology, 38(2), 168-172. doi: 10.1037/h0055873

Skinner, B. F. (1953). Science and human behavior. New York: Macmillan.

Skinner, J., Zakus, D. H., \& Cowell, J. (2008). Development through sport: Building social capital in disadvantaged communities. Sport Management Review, 11(3), 253-275. doi: 10.1016/S1441-3523(08)70112-8 
Spaaij, R., \& Westerbeek, H. (2010). Sport business and social capital: A contradiction in terms? Sport in Society, 13(9), 1356-1373. doi: 10.1080/17430437.2010.510674

Thompson, J. B. (1995). The media and modernity: A social theory of the media. Stanford, CA: Stanford University Press.

Thorndike, E. L. (1931). Human learning. New York: AppletonCentury Crofts.

Thorson, E., Chi, A., \& Leavitt, C. (1992). Attention, memory, attitude, and conation: A test of the advertising hierarchy. In J. F. Sherry \& B. Sternthal (Eds.), Advances in consumer research (Vol. 19, pp. 366-379). Provo, UT: Association for Consumer Research.

Trail, G. T., Fink, J. S., \& Anderson, D. F. (2003). Sport spectator consumption behavior. Sport Marketing Quarterly, 12(1), 8-17.

Tversky, A., \& Kahneman, D. (1973). Availability: A heuristic for judging frequency and probability. Cognitive Psychology, 5(2), 207-232. doi: 10.1016/0010-0285(73)90033-9

Uhrich, S., \& Benkenstein, M. (2010). Sport stadium atmosphere: Formative and reflective indicators for operationalizing the construct. Journal of Sport Management, 24(2), 211-237. doi: $10.1123 / \mathrm{jsm} .24 .2 .211$

Van Leeuwen, L., Quick, S., \& Daniel, K. (2002). The sport spectator satisfaction model: A conceptual framework for understanding the satisfaction of spectators. Sport Management Review, 5(2), 99-128. doi: 10.1016/S1441-3523(02)70063-6

Vargo, S. L., \& Lusch, R. F. (2016). Institutions and axioms: An extension and update of service-dominant logic. Journal of the Academy of Marketing Science, 44(1), 5-23. doi: 10.1007/ s11747-015-0456-3

Vargo, S. L., Maglio, P. P., \& Akaka, M. A. (2008). On value and value co-creation: A service systems and service logic perspective. European Management Journal, 26(3), 145-152. doi: 10.1016/j.emj.2008.04.003

Wakita, T., Ueshima, N., \& Noguchi, H. (2012). Psychological distance between categories in the likert scale. Educational and Psychological Measurement, 72(4), 533-546. doi: 10.1177/0013164411431162

Walker, M., Heere, B., Parent, M. M., \& Drane, D. (2010). Social responsibility and the Olympic Games: The mediating role of consumer attributions. Journal of Business Ethics, 95(4), 659-680. doi: 10.1007/s10551-010-0445-x

Woolcock, M. (1998). Social Capital and Economic Development: Towards a Theoretical Synthesis and Policy Framework. Theory and Society, 27(2), 151-208. doi: 10.1023/A:1006884930135

Wooldridge, J. M. (2013). Introductory econometrics: A modern approach (5th ed.). Mason, $\mathrm{OH}$ : South-Western.

Woratschek, H., Horbel, C., \& Popp, B. (2014). The sport value framework - a new fundamental logic for analyses in sport management. European Sport Management Quarterly, 14(1), 6-24. doi: 10.1080/16184742.2013.865776

Woratschek, H., Durchholz, C., Maier, C., \& Ströbel, T. (2017). Innovations in sport management: The role of motivations and value cocreation at public viewing events. Event Man- agement, 21(1), 1-12. doi: 10.3727/152599516X1478635033 7262

Xing, X., Church, A. G., O'Reilly, N., Pegoraro, A., Nadeau, J., Heslop, L., \& Séguin, B. (2008). Olympic Games host and bid city marketing: Exploring issue management in the relationships among event stakeholder groups. International Journal of Sports Marketing and Sponsorship, 9(4), 77-91. doi: 10.1108/ijsms-09-04-2008-b009 